\title{
Fishing for export: calo, recruiters, informality, and debt in international supply chains
}

\author{
KATHARINE JONES, DAVID VISSER \\ and AGNES SIMIC
}

\begin{abstract}
This article represents the first study to conduct a comprehensive review of employment practices within the Indonesian export fishing industry, the world's largest exporter of tuna products. In contrast to the Thai and Taiwanese fishing industries which engage primarily migrant fishers, fishers in Indonesia are Indonesian nationals, although many are internal migrants. We make two arguments. Firstly, that some of the same risks of forced labour - in hiring and employment practices - exist even where the workforce are domestic rather than international migrants. Secondly, our research identified that informal employment relations inherent in small-scale traditional fishing have been co-opted by businesses as a means of reducing labour costs while maximising their profits. Recruitment was an area of particular risk for exploitation of fishers. Our research has implications for companies sourcing from Indonesia as well governments of import companies. In particular, we argue that a narrow focus on modern slavery risks inadequate or even counterproductive policy responses.
\end{abstract}

Keywords: Fishing, seafood, supply chains, Indonesia, fishers, recruitment.

\section{INTRODUCTION}

Seafood is big business. It is one of the most traded food commodities worldwide and generates more revenue than meat, tobacco, rice, and sugar combined (FAO 2016). An increased appetite for fish in Western food markets coupled with technological innovation which allows fresh catch to be transported around the globe has quadrupled trade over the past half century (FAO 2018). For business and for consumers seafood is a success story. However, for our oceans and for the people in the low-income countries catching and processing fish, the costs and risks of this global industry are substantial. According to the United Nations, nearly 90 per cent of the world's marine stocks are now fully exploited, over-exploited, or completely depleted (UNCTAD 2018). 
For the past decade, journalists and human rights organisations have reported the trafficking, forced labour, and even murder of fishers in the Asia-Pacific (EJF 2018a, 2018b, Greenpeace 2018, McDowell et al. 2015). The European Union (EU), the United States, and Japan account for around two-thirds of the global value of seafood imports (FAO 2018: 7). Yet, our understanding of the relationship between conditions in fishing in the Asia-Pacific and the business practices of international companies in consumer markets is still limited.

To date, empirical research in this region has primarily been conducted in Thailand (e.g., Vandergeest et al. 2017), or on the conditions of the estimated 250,000 Indonesian fishers who are recruited onto Taiwanese vessels (Greenpeace 2018). In both cases, studies have focussed predominantly on the trafficking and forced labour of fishers. This article contributes to knowledge about the working conditions of fishers in Indonesia who catch for export. Indonesia is the world's second largest producer of seafood after China. Despite this, to the best of our knowledge, this is the first study to conduct an in-depth review of employment practices within the Indonesia export fishing industry. In contrast to the Thai fishing industry, which relies on the labour of migrant fishers, fishers in Indonesia are Indonesian nationals, although many are internal migrants. We make two unique contributions to the literature. Firstly, we challenge the assumption in the literature that labour risks in fishing arise out of fishers' migrant status. We argue that some of the same risks of forced labour - in hiring and employment practices - exist even where the workforce are domestic rather than international migrants. Secondly, our research identified that informal employment relations inherent in small-scale traditional fishing have been co-opted by businesses as a means of reducing labour costs while maximising their profits (Duong 2018, Tickler et al. 2018). Overall, we found that labour conditions in Indonesia's export seafood industry are generally poor. Fishers receive little remuneration for 'dirty, demanding, and dangerous' labour and many are in perpetual cycles of debt.

The findings in this qualitative study have been collected and analysed by Coventry University in partnership with the Centre for Sustainable Ocean Policy at University of Indonesia and IOM (International Organization for Migration) Indonesia. ${ }^{1}$ In total, five field-sites in Indonesia, all playing a widely recognised and substantial role in the seafood export industry, were selected by the project team. These were Benoa (located on the island of Bali), Bitung (North Sulawesi), Mauru Baru (Jakarta, Java island), Ambon (Maluku, Eastern Indonesia), and Tegal (Central Java). Bahasa Indonesia-speaking research staff conducted 142 interviews: 50 fishers, 25 canning factory workers, 27 stakeholders (government officials, non-governmental organisation

\footnotetext{
${ }^{1}$ The findings reported in this paper are part of a larger study conducted with the Issara Institute.
} 
(NGO) and fishermen's association representatives), 10 recruiters, and 30 company representatives. The majority of the interviews were digitally recorded with consent and then translated and transcribed. The interviews that were not digitally recorded instead relied on extensive handwritten notes. Thematic analysis was carried out to best capture the themes and issues being raised and the relative importance of these concerns from across the sample.

\section{TRAFFICKING AND FORCED LABOUR IN FISHING FOR EXPORT}

To date the vast majority of empirical data on labour conditions within the exporting seafood industry in the Asia-Pacific has been collected within the Greater Mekong region (EJF 2018a, 2018b, Human Rights Watch 2018, IOM 2016; Issara Institute \& IJM 2017, UNODC 2017). The focus of this research, much of which originates via human rights reports, concerns itself with identifying the victims of trafficking and forced labour, their experiences, and, in a few instances, their abusers (Bélanger 2014, Derks 2010, Marschke \& Vandergeest 2016, Vandergeest et al. 2017). Most of this literature explores the situation of migrant fishers who have crossed international borders. Major identified indicators of trafficking and forced labour include debt-bondage, violence at sea, deception, forced confinement, and even murder (EJF 2018b, Issara Institute \& IJM 2017).

These studies find that, in general, working conditions for migrants on board vessels are poor. Fishing is highly labour intensive, as fishers typically have to work for twenty hours a day, every day of the week whilst at sea (Vandergeest et al. 2017). Fishing is a dangerous occupation, and fishers often have to take risks in operating hazardous machinery in stormy weather (Derks 2010, Issara Institute \& IJM 2017). Vessels often lack proper sleeping quarters, or even mattresses and blankets (Robertson 2011, Stringer et al. 2011). Personal hygiene is often an issue, as fishers may be required to wash in salt water and vessels may lack toilet facilities (Devlin 2009, Issara Institute \& IJM 2017, Stringer et al. 2011). Fresh water for drinking is typically scarce, especially when vessels have been at sea for prolonged periods of time (Stringer et al. 2011, Surtees 2008). Unsurprisingly, diseases associated with vitamin deficiency arising out of poor-quality and insufficient food are commonly suffered by fishers on board these vessels (Devlin 2009, Stringer et al. 2011).

Within this literature, human trafficking and forced labour on vessels are largely attributed to insufficient inspection, policing, monitoring, and regulation of the fishing industry (IOM 2016). According to this argument, the vulnerability of crews to abuses increases the deeper at sea the vessel fishes. This is because it is more difficult for the authorities to maintain oversight of working conditions (de Coning 
2011, EJF 2015, Robertson 2011). Without oversight by authorities, fishers find it difficult to report abuse and to seek assistance, while at the same time, labour organising and membership of trade unions remain rare (Robertson 2011). For some authors, it is criminals and unscrupulous actors who are responsible for trafficking (Chapsos \& Hamilton 2018). In this analysis, exploitation is an aberration rather than arising out of prevailing market conditions or systemic unfairness (Fudge 2017).

A more sophisticated and persuasive analysis situates the exploitation of fishers as being driven by an increased global demand for fish and the rapid growth of industrial fishing fleets, as well as the over-exploitation of several fish stocks (ILO 2013). This analysis echoes critiques of modern slavery which view free/unfree labour as arising out of the political economy of transnational capitalist modes of production (e.g., Fudge 2017, LeBaron 2015, Strauss \& Fudge 2013). Falling productivity arising out of intensification of fishing methods and the consequent depletion of fish stocks induces vessel owners to cut operating costs to maintain or increase profits. They do this through fishing illegally, catching fish in territories where they are not legally allowed to do so, catching more than quotas allow, or catching species of fish which they are not supposed to (Agnew \& Barnes 2004). It is the depletion of fish stocks through hyper-intensification which drives fishing vessels further out to sea and for longer periods to maximise their catch. However, such long-distance fishing operations are labour-intensive and expensive. Crew wages can account for between a third and half of all operating costs (Kelleher et al. 2009). Companies seek to maximise their profitability by aggressively reducing expenditure on crew: for example, by non-compliance with labour and safety standards or by withholding pay (Tickler et al. 2018: 2). They also do this through hiring migrant fishers who can be persuaded to work for less than the average wage (Agnew \& Barnes 2004, Tickler et al. 2018). Migrant workers can also be more easily controlled through confiscation of their ID documents, which physically prevents them from leaving vessels (Issara Institute \& IJM 2017, Robertson 2011). Further, the recruitment process in which migrant labourers are sourced by agencies in one jurisdiction and employed by fishing operators in another, means that fishers can easily be deceived when embarking the fishing vessel and can be coerced into accepting employment contracts or agreements on lesser terms than initially discussed (EJF 2018a, Stringer et al. 2011, Surtees 2008). Exploitation arises because migrants are dependent on their recruiter for knowledge, identity and work permit documents, and for employment contracts. Fishers usually pay a fee to the recruiter, which often leads them into debt-bondage, a key indicator of forced labour (Jones et al. 2017). A recent, large-scale survey of the prevalence of human trafficking in the Thai fishing industry found that three quarters of fishers sampled were bonded to vessel captains or the vessel-owning companies by debt 
incurred through high recruitment fees (Issara Institute \& IJM 2017). In summary, the existing literature leaves a gap in knowledge about working conditions in the Indonesian export fishing industry where fishers are not migrants. This gap is addressed in this article, which now moves on to provide an overview of the context in Indonesia.

\section{DEFINED BY THE SEA: FISHING IN INDONESIA}

This article examines the working conditions of fishers catching fish in Indonesian waters for export to US and European markets. When compared to the literature reviewed above, in particular that which reports conditions in Thailand, there is one substantial difference: Indonesia's fishing vessels are crewed almost wholly by Indonesian nationals rather than by migrants. In 2015, an Associated Press investigation directed the world's attention to the Indonesian islands of Benjina and Ambon where 1,300 fishermen from Cambodia, Myanmar, Laos, and Thailand were rescued from Thai fishing vessels grounded as a result of a moratorium imposed on 'foreign' fishing vessels by the Indonesian government (McDowell et al. 2015). Engaged in catching fish which ended up on the shelves of well-known supermarkets, the fishermen had, in some cases, endured years of violence and abuse at the hands of the vessel captains and owners (IOM 2016, McDowell et al. 2015). Partly as a result of the ensuing international media attention, the Indonesian government amplified implementation of a ban on illegal fishing and took action against the use of (ex-)foreign fishing vessels in its waters. Acting on requests from the government, since then the Indonesian navy has impounded and blown up over 400 foreign vessels (owned by Thailand, Taiwan, and China) (Hutton 2017). Subsequently, international migrant fishers are no longer evident in the Indonesian fishing industry which produces for export. Many are, however, internal migrants. The majority of Indonesian fishers originate from the north coast of the island of Java, which has a reputation for being both a region of fishing as well as 'producing' fishermen who work elsewhere in Indonesia and overseas on foreign vessels.

Indonesia is defined by the sea. As an archipelago with over 17,000 islands and a coastline of 55,000 kilometres, two thirds of the Indonesian population live in coastal areas, with two thirds of these working in the fishing industries. Indonesia is the second largest producer of marine fisheries in the world, after China. It accounts for almost half of all seafood production within the South East Asia region (FAO 2018). However, quite remarkably, almost 95 per cent of all fish is caught and produced for the domestic market, with only 5 per cent going for export (Packard Foundation 2018). This 5 per cent is, nevertheless, substantial, with exports 
amounting to US $\$ 2.3$ billion for the first six months of 2018 , and tuna-its most valuable export - quadrupling in value between 2000 and 2016, to US\$569 million per annum. ${ }^{2}$ The United States is the primary destination of exports ( 30 per cent), followed by Japan (23 per cent) and Europe (13\%) (Seafood Trade Intelligence Portal n.d.). The United Kingdom is a relatively low importer of Indonesian seafood products (HMRC 2017; referred to in Seafish, 2017).

Historically, Indonesia has been the subject of substantial illegal fishing, primarily by Thai, Taiwanese, and Chinese industrial-sized trawlers, which landed their catch in their own ports, denying Indonesia any value from the fish (Sunoko \& Huang 2014). As well as impacting on Indonesia's economy, overfishing, mostly by the trawlers - but also resulting from non-sustainable forms of fishing in general - has led to a dramatic decline in overall fish stocks and the disappearance of some species altogether from Indonesian waters (Packard Foundation 2018). This means that fishing is largely no longer a sustainable occupation in Indonesia, with many traditional fishers living below the poverty line (Prima et al. 2015). In 2014, in an attempt to redress this situation, President Joko Widodo launched his ambition to transform Indonesia into the world's leading maritime power. As one of his first acts, he appointed the charismatic Susi Pudiiastuti as Minister of Marine Affairs. 'Bu Susi', as she is affectionately known at home and abroad, promptly set highly ambitious new export production growth targets of up to 80 per cent for the industry. To try to achieve this, she opened up foreign investment into the industry and advocated for the reduction of international import tariffs for Indonesian seafood products to the same level as those enjoyed by Indonesia's competitor seafood-producing countries (e.g., Vietnam). In December 2018, Indonesia concluded a free trade agreement for seafood with the countries of EFTA (the European Free Trade Association) (Norway, Switzerland, Iceland, and Lichtenstein), with a similar agreement with the European Union expected to follow. This indicates both the scale of Indonesia's global seafood ambitions as well the timeliness of this research.

Globally, one of the key challenges for enhancing the labour rights of fishers is their lack of recognition as salaried employees (ILO 2016). This challenge arises out of the construction and representation of fishing as a 'traditional', small-scale, occupation in which families and wider kin support themselves in the global economy. In traditional fishing, fishers receive a share of the profits from the sale of the catch rather than a salary. For this reason, for decades, the International Labour Organization (ILO) has debated the definition of 'fishers' as informal self-employed versus employees (ILO 2018). ILO Convention C188 Work in Fishing, 2007 (ILO 2007)

${ }^{2}$ https://www.tridge.com/intelligences/tuna/ID 
grapples with this through setting labour standards regarding safety and hygiene on board vessels, hours of rest, (non-)hiring of child labour, and the use of signed work agreements regardless of fishers' status. In 2016, as part of moves to ratify C188, Indonesia introduced a series of laws aimed at professionalising the employment of fishers, including the adoption of a minimum daily wage for fishers crewing vessels larger than 30 gross tonnage. At the time of writing, the daily wage is set at 60,000 IDR (US\$4.20) payable only for the time fishers spent on board the vessel catching fish. According to the law, wages can be supplemented by a 'premi' (bonus) resulting from a share of the profits of the sale of the catch. We now move on to consider the empirical data and its analysis.

\section{'SOMEONE I KNEW CAME TO MY VILLAGE': HIRING FISHERS IN THE INDONESIA DOMESTIC INDUSTRY}

In Indonesia, the domestic fishing crews are recruited in three main ways: kinship networks, 'walk-up' labour, and intermediaries, known as calo. Firstly, where possible, vessel captains recruit their crew from among their friends, extended kin, and neighbours. As noted above, many of the fishers in Indonesia working in the domestic industry come from north central Java. This means that the informal networks which underpin recruitment are highly embedded in these communities. This is also the traditional way for captains to find crews for their boats in small-scale sustainable fishing.

Oh, I already knew the captain. He is from the same village as I am. After being there for a while and getting to know more people, I went home for a bit-but as soon as I arrived he called me again and I went back. It tends to happen like this there-I've already worked on ten boats, but for different companies.

fisher interviewed in Bitung (November 2018)

Secondly, vessel captains operating out of the large ports of Mauru Baru and Bitung recruit their crews from among the men who hang around port areas seeking work. This tends to be men who have disembarked from voyages as well as fishers who live locally and who will literally 'walk-up' to vessels seeking their next job. Again, this is a traditional way for captains to find crews.

We ask around whether the ship is lacking $A B K$ [fishing crew]. We also ask about when the ship is sailing. We will then meet the second person who is going to introduce us to the captain. We'll just ask the captain. If there's a vacancy, we'll go on board, if not, we'll find another ship.

fisher interviewed in Ambon (November 2018) 
Thirdly, intermediaries known as 'calo' recruit crews on behalf of captains and fishing companies. Captains and vessel-owning companies utilise calo where they are unable to find sufficient crew members, largely where there is no available local labour force. We found that calo were in use in Benoa, Ambon, Bitung, and Maura Baru. Like the captains, calo find crews from among their own extended social networks and visit the villages and neighbourhoods ('kampungs') in coastal communities which are known for fishing. These include Tegal, Sumatra, West Nusa Tenggara, and East Nusa Tenggara. They also operate in port areas referring the walk-up crews to available vessels. For brokering the employment, calo may charge a fee to the captain, the company, or to the recruit. While some may have other jobs, supplementing their income through recruitment, others do this full-time. Calo are similar to those who are known as brokers, dalals, of sponsors (Jones et al. 2017, Lindquist 2010) in other places and in other economic sectors, and operate in the informal economy. In Benoa and Ambon, interviewed fishers highlighted the propensity for local 'gangsters' known as 'preman' to also be involved in this work.

We bring them by a plane. Once found and gathered a number of the crew that we need, we would buy them a ticket ... they're mostly from Java. Sometimes we got crews from there, but when we got them from there we would buy them a flight ticket from Java to Bali. ... Then to Ambon, transit in Makassar. My friend from Java organises this all for a fee of 100 [IDR] per crew.

vessel captain operating out of Ambon and Benoa (interviewed November 2018)

As in Thailand and elsewhere (Vandergeest et al. 2017), interviewees for this study had experienced exploitation at the hands of the intermediaries which they had not experienced when recruited onto vessels through kinship networks or walk-ups. Most frequently mentioned was through the fees charged by calo to fishers, of up to two or three million IDR (approximately US\$150 to US\$200), ostensibly to cover transport costs. While occasionally crews are flown to Bali, most often transportation is arranged by van and ferry. However, crews do not pay this up-front, as individuals in fishing communities such as Tegal do not have access to this level of money. The fee is typically structured as a 'cash advance' (known as a 'kas bon') which is paid to crews as a down payment before they depart. Calo use the offer of a kas bon to entice potential crew to leave with them. It is through the kas bon, which becomes a form of personal debt that exploitation occurs.

My family and all my neighbours are fishermen. We come from the 'Fishermen Kampung'. ... Someone I knew came to my village and told me they could give me money. I was told that I would get three million rupiah [US\$200] to go to Benoa. I took a bus from my village to Benoa. This took four days. I worked on a longline ship with people from my village. 
The kas bon money, which comes from the vessel-owning companies, is used to buy food and other household supplies to maintain families while fishers are at sea. Rather than something which is specific to calo, however, kas bon is a common practice throughout the traditional fishing industry in Indonesia, regardless of whether intermediaries are involved or not. Traditionally, the kas bon functions as an informal system of credit which supports fishers and their families while they are at sea. Advances are deducted from the fishers' earnings at the end of the voyage:

Kas bon is to borrow some money. Well sometimes 400,000 IDR [US\$28], sometimes 1,000,000 IDR [US\$70]. It depends on the needs in the house.

fisher, interviewed in Tegal (August 2018)

In this case however, the kas bon is not primarily utilised to help fishers. Calo utilise the opportunity to extort money from fishers before and after the voyage. Interviewees related examples - of their own as well as of others-where calo persuade recruits to leave home with promises of large cash advances which are not then handed over. Calo commonly retain the bulk of money from the company for themselves.

Yes, and there are a lot of middlemen in the port, middlemen for $A B K$ [fishers]. Well they will persuade the candidates, I don't know what they say exactly but they will say sugar-coated stuffs. ... Like yesterday, I have a friend from one ship, he was sent by a middleman. He only got 500,000 IDR [US\$35] from the actual amount of three million [US\$210] [of kas bon from the company]. So how much did the middleman get? 2.5 million [US\$175] cash advance. Cash advance for the calo!

fisher interviewed in Tegal (August 2018)

Calo interviewed for this project confirmed that, while crews typically only receive a small amount of kas bon - for example, three to four million IDR (US\$210-280) companies actually forward ten million IDR (US\$700) to them (the calo) for each fisher recruited. Between six and seven million IDR is retained by calo as their fee while the full advance of ten million IDR (US\$700) is deducted from the fisher's salary at the end of the voyage.

As well as extracting a portion of money from the kas bon, calo also find ways to extort additional money from crews. This research found that calo in Benoa organise temporary accommodation (known as 'the mess') for fishers who arrive in Bali but have a few days or weeks to wait until their ship departs. High rents are deducted from the portion of the kas bon which is given to fishers. Calo also encourage recruits to buy food and alcohol and to access sex workers, the cost of which is also deducted from the kas bon. In Benoa, researchers saw it was clear that the calo had interests in the local shops, restaurants, and sex work industry in the port area. As the kas bon is typically given immediately prior to fishers' departure, they are not able to challenge such deductions. 
I work for $M r$. X. [interviewee names a locally known gangster] We are brothers. ${ }^{3}$ I often go home and help my fellow village. Just this time I was back and I am bringing five more people here. We receive advance of ten million [US\$700] per person from the company. We give three to four million [US\$210 to 280] to the candidate. We tell him he must give half to his wife back in the village. The other half he is free to spend here in Benoa on food and accommodation. We also help with the sex workers. Drinks. Whatever he needs he can have. We help with this. I rent a house. There is a room there. They stay there until there is a ship. We negotiate the ships. Could be one day or two months, depends till we find a ship.

calo working in Benoa (interviewed June 2018)

Prior research on intermediaries which broker employment in commercial fishing as well as in other sectors identifies high recruitment fees as an important way in which recruits are extorted money they are owed (Jones et al. 2017). As workers get into debt to pay the fee, their employment becomes bonded, as workers are unable to leave until they repay the money advanced, often leaving little or no earnings at the end of the employment. The literature associates the risk of entering this form of debt-bondage with the vulnerabilities of being an (international) migrant worker (Issara Institute \& IJM 2017). Yet this research has found that intermediaries-in this case, calo-function as extorters even where the migration takes place within the recruit's own country.

Moreover, as has been found in research on international recruitment in other sectors (Jones 2014), calo in Indonesia do not just extort fishermen monetarily, they also function as a guarantee or 'bond' to captains and fishing companies that the crew will remain with the vessel. For companies, advancing a cash kas bon has the risk that the recipient will decide to leave with the money and abandon the voyage, leaving them out of pocket. For companies, advancing the kas bon through the calo passes to them the responsibility that they will ensure that the fisher gets - and stays - on the vessel until he has earned sufficient to repay the advance. In effect, calo indirectly and directly, function as labour 'enforcers'. It is for this reason, calo argue, they retain the six million IDR from the company kas bon:

[The other six million rupiah, US\$419] is our guarantee. We guarantee them. If they run away the companies make us pay. They lose money. It is us that bear the debt. And the burden. So we keep that until they finish their contract.

calo interviewed in Benoa port (June 2018)

This research also found that in Benoa the role of the calo does not end with brokering recruitment or arranging the kas bon prior to departure. In fact, they are often responsible for disbursing payment of their recruits' wages at the end of the

${ }^{3}$ In this context, the Indonesian word used refers to someone who may literally be a kin relationship, but more likely a close contact who is a 'fictive kin'. 
voyage. This enables them to take charge of all the money flowing to the crew, from the kas bon which is advanced to the crew, to the deductions which are made from crew from their salary. According to interviewed fishers, calo also try to extract more money at this point. There are extra charges applied without any credible evidence they have been made, and fishers may even be forced to buy their tickets back home through the calo at inflated costs:

After a trip, we usually get our pay. The frustrating thing is we usually get pulled aside by the preman [calo], who are waiting for us in their cars, and strongly encourage us to go spend our money at their shops. They make us buy our tickets home through them too.

fisher interviewed Benoa port (August 2018)

Interviewees reported that at times, calo took all of their recruits' wages through such deductions, leaving fishers with no money at the end of a voyage. This can be used to force fishers to get back onto the vessel for a further voyage rather than go home. It can be, in this sense, a continuous cycle:

I often worked thirty hours and then sleep. It was very hard. We had to pay for our food. For three months. When I wanted to go home for Lebaran [Eid], I left but I did not receive any money. My captain told me that he had paid my wages to the calo. But the calo threatened me and told me that I had spent all my wages. They have agreed to pay me if I go back again. But for now I have no money.

fisher interviewed Benoa port (August 2018)

As has been found with other research on recruiters in other sectors, calo are deeply embedded in pre-existing social relations within communities rather than a separate 'industry' (Fernandez 2013). Their function here, though, is less about helping kin and neighbours to find work but to supply a continuous stream of low-cost workers to vessel owners. Principally, the calo are used to locate and arrange transportation for fishers who live elsewhere where there are insufficient crew locally. Their function as intermediaries is to connect employers (vessel owners and captains) with workers (fishers) in situations where they would otherwise find it difficult to find them (Jones 2014). Their role is also to supply a particular type of labour: men who are willing — or who are coerced into-working into a job which is dangerous, dirty, and for which they earn little money.

\section{'THERE ARE MANY ABK FISHERS EXPLOITED': EMPLOYMENT PRACTICES IN EXPORT FISHING IN INDONESIA}

Few of the fishers interviewed for the current study had received a written work agreement (known as the 'PKL' in Indonesia), despite this being a requirement according to Indonesian law. As elsewhere in the commercial fishing sector, working 
relationships are kept informal and reliant on the direction of the captain. Verbal agreements constitute a brief discussion with the captain about the expected length of the trip, what species they are intending to catch, and how the crew will be paid:

They don't have fair contract system between the workers and the owner. The contract system is only a verbal contract: 'If you want to work on my vessel, please come on.' It's only like that.

fisher interviewed in Tegal (June 2018)

Consequently, interviewees experienced highly variable working conditions on vessels, depending on how large the vessel was, how long it remained at sea, what species of fish they were catching (and therefore how intensive the fishing was), and what company owned the vessel. While fishing was acknowledged to be an occupation which rarely involves standard hours because of the nature of the industry, interviewees reported that working hours were largely dependent on the captain or the company's established working practices:

The working condition can be inhumane. We can work for twenty-four hours a day sometimes. Sometimes we have to work at night with no rest. When all is set, we get a break, sometimes only four hours a day.

fisher, interviewed Tegal (June 2018)

According to interviewees, small areas on the boat, often shared with the kitchen facilities, are sometimes allocated for rest but fishers prefer to sleep outdoors because the inside spaces are too cramped:

Another issue is the sleeping spacelroom, which is too small for twenty to twenty-five people, and thereby sometimes we can only sleep while sitting because there is not enough proper place.

fisher interviewed Tegal (November 2018)

Fishers are not allowed to eat the seafood catch, which is intended for sale, with two meals of rice per day commonly allowed. In addition, crews typically have access to packets of instant noodles for snacks with the costs of these deducted from their salaries. While better than many situations reported by studies of the Thai industry, fishers interviewed did report running out of food when the vessels had been at sea for long periods of time or when insufficient supplies had been purchased by the captain:

Sometimes we weren't given enough food. We only provided drink but no food. If the boat had run out of food, then we just let it go. We may only cook the basic food because there is no snack. We have water, fresh water, but we bring it ourselves. We sometimes use melted ice block for drinking water. Sometimes the captain wasn't really caring about the crews. He never gives us food and he eat everything himself.

fisher interviewed Tegal, (November 2018) 
That said, interviewees who had crewed squid boats, which are often at sea for ten months at a time, noted the working conditions to be especially challenging. In part, fishers associated this with the greater length of time at sea on such squid boats (up to ten months) and the type of fishing involved, which necessitates working through the night. Beri beri, a vitamin deficiency disease similar to scurvy and which has commonly been found in migrant crews on Thai, Taiwanese, and Chinese vessels, was also frequently discussed by Indonesian fishers who had crewed squid boats:

Squid fishing also makes us get sick quite easily. People regularly get very swollen feet and beri beri. They are quite itchy, because they aren't given deck shoes and regularly get exposure to saltwater.

fisher interviewed Tegal (June 2018)

Studies on the Thai industry have found violence on vessels to be common. For instance, one report found that one in five fishers experience violence (Issara Institute \& IJM 2017). In comparison, examples of physical violence on board Indonesian vessels were infrequently shared by interviewees, with the exception of some isolated incidences. Such incidents appear to be associated with specific captains with reputations for violence, rather than structural or endemic throughout the industry in Indonesia. Violence in the form of punishment was usually associated with incidences where the valuable catch had been damaged:

There is a form of 'code' on board, with certain punishments. For example, if I make a mistake, during the rest time between sets of one to two hours I won't be allowed to rest. Notes are kept on this, so when our friends are sleeping we will be forced to stay awake. ... Say we toss the mainline and damage or lose it - that'll be counted. Or, we hook the fish in the wrong way, don't follow orders immediately - that also gets punished. .... We use a gaff hook to lift them on board. We are meant to get them in the head so we don't damage the flesh. If we get the body of the fish, we get a punishment.

fisher interviewed Tegal (June 2018)

Crews demonstrated little awareness of their legal rights, accepting poor conditions as simply part of their lot in life as poor men who became fishers. Even where interviewees were aware of laws intended to protect them, which wasn't often, the informality within the system meant that asserting these rights was usually not possible. Fishers in Indonesia are not members of trade unions, with traditional unions finding it difficult in Indonesia, as elsewhere, to operate in the industry. Crews were acutely aware that, if they complained, they were unlikely to be given much payment by the captain or be able to arrange work in the future with that captain:

I didn't feel comfortable to complain about salary on my first year. Many of my colleagues have been working for five to six years on that vessel. None of them complained about the salary. It was also because the captain and the 'deputy I' and 'deputy II' are relatives. 
Of course if we complained about the work, of course he would defend his brothers. It's such a waste of energy, I thought.

fisher, interviewed in Tegal (June 2018)

Working conditions on fishing vessels can be dangerous and extremely difficult whether the catch is for export or whether the fishing is undertaken within traditional, small-scale fishing. Yet, there are some differences. Where fishers work on vessels owned by exporting companies, captains are under immense pressure from companies to ensure that they maximise the catch landed. This means maximising the work effort:

The captains are responsible for the work environment. But they also receive immense pressure from the company. Say he is given a quota of eighty tonnes-but over a year, he only gets fifty. He still needs to find that extra thirty tonnes.

company representative, Ambon (November 2018)

According to interviewees, one way that companies and captains do this is through the use of calo, not just to recruit and management payments for fishers, but also to enforce compliance. Calo are also involved in enforcing compliance among crews perceived by captains (or companies) not to be working hard enough or who want to leave in advance of their contract ending. This is a form of pressure to enable greater exploitation of individual workers as well as disciplining of the crew more generally via an extreme 24/7 work ethic:

The biggest one is Balinese, but the underlings are usually from other places. They tend to be quite close too - usually related through marriage. Sometimes if a distant relative is unemployed, they'll call them up to be a field coordinator or to 'instruct' the lazier $A B K$ [fisher]. The collecting division is where most of the 'punchers' are. Even before the vessel has properly docked, they'll be asking the ones who call sick, 'What's made you sick?!' They'll take him to a doctor - if the doctor says the ABK isn't sick, the ABK will be taken to the office and beaten.

fisher interviewed Benoa (June 2018)

Moreover, this research found multiple incidences of where fishers' identity cards were retained by vessel captains to ensure that crews remain with the ship until the catch is landed and sold and kas bons are repaid. If catch sales do not cover the amount, then the fishers remain in debt and their ID is retained. This type of 'enforced compliance' is a clear indicator of forced labour (ILO 2017):

I just would like to say, don't just talk about slavery in abroad. In domestic vessels, there are many ABK fishers exploited.

representative from fishermen's association, NG1 (April 2018) 
Interviewees understood the purpose of the retention of their ID card to be about guaranteeing that they would stay with the vessel. Interviewees spoke about having to return to sea with the same company, sometimes multiple times, to work off accrued debts. When their debt is not paid off, this means that they are unable to leave the vessel as they are not able to afford to go home:

This is also a loan so I keep changing, but my ID card is being held. ... yes detained. ... Yes, guarantee that I won't change anytime. ... It's hard.

fisher, Bitung (December 2018)

The retention of identity documents to enforce compliance or to tie a worker to her or his place of employment is usually associated with migrant workforces. For instance, in Thailand, as in other countries, where migrant fishers are engaged, the confiscation of identity cards to retain control of the crew is common (Vandergeest et al. 2017). NGO interviewees in this study noted that the major difference between working conditions in the Indonesian domestic industry and those elsewhere where a migrant workforce is involved is that fishers can simply leave and go home if they did not like the work - even if they would be out of pocket financially. However, the risk of crew leaving when the captain needs them to stay is not only one related to having sufficient workforce. It is also a direct financial risk if the company has advanced the crew kas bon. According to captains interviewed, companies hold them responsible for this:

Well, [crew running away] is part of the risk. The captain needs to be held accountable for that. Therefore, when the crew runs away, the captain will have to pay ...

captain interviewed Ambon (November 2018)

In short, even where the fishing workforce are not migrants, to maximise profitability similar exploitative practices are deployed within the industry to intensify catch effort on board vessels while reducing the risks of fishers leaving.

\section{'THE COSTS ARE OUR DEBT': PAYMENT TO FISHERS IN INDONESIA}

This research found that only the fishers on the larger vessels catching for export were provided with a daily wage by companies, as required under Indonesian law. For the most part, fishers, although catching for export, are still only provided with a percentage of the total amount of the sale of their combined catch from their vessel, with final payment made at the end of the voyage. In Indonesia as elsewhere, fishers operating vessels with their families and neighbours share more-or-less equally in the money which is made once the fish is sold. Profit-share functions to ensure that families and friends operating boats together all profit from the joint operation: 
I met the captain ... he said it was good to work here and I'd be paid by sharing income ... it depends on the number of tuna. If we gain a lot of them, the crews can receive more, otherwise they'll receive less.

fisher interviewed in Ambon (June 2018)

Where the catch is substantial, the profit-share amount crews receive may work out above what they would have received through a daily minimum wage. However, this research has found that at other times, what crews receive may work out as less due to deductions for kas bon and costs charged by calo - where one is involved - and by the captain. Costs can be charged for food and cigarettes consumed on board. Fishers are typically also charged for the cost of the fishing nets.

Ah, if we are lucky we receive three to four million IDR [US\$20 to US\$28] per month. Sometimes we get paid sixty thousand IDR [US\$4] per day. Or sometimes it equals out to seventy or eighty thousand IDR [US5 to US\$5.50] per day. It depends if the fishing is good or not.

fisher interviewed in Tegal (January 2018)

They are also paid below the minimum wage. Normally in Muara Baru they are paid sixty thousand IDR [US\$4] per day before deductions for food and ancillary items.

fisherman's association representative, Jakarta (October 2018)

The nature of fishery payment systems evidenced in this research allowed for deception at worst, or lack of clarity at best. Full transparency and clarity in distribution of wages was uncommon. Many interviewees were not sure how fair their profit-share allocation was, vis-à-vis other crew members on board who may be closer to the captain. Fishers also only know how much they will receive when they are told by the captain - or the calo - at the end of the voyage. They are aware that what they think may be the price of the catch when they set out, and therefore what they might expect to earn, may not be the actual price when they get to port. This means that fishers are not able to plan for the amounts they will receive.

It doesn't matter whether the fish are fresh or frozen since we always hand over the catch to the company. All the payment [for the fish] are done to the company directly. As I said, the company has many boats. So, they usually collect and weigh the catch at the port and take the catch directly to the company [factory]. They will later pay us.... If we unload them in the morning, we will receive the salary at night.

fisher, interviewed Bitung (December 2018)

Where interviewees did not know or did not like the captain, they were more likely to be suspicious that they had been 'cheated' out of their share. Interviewed crews and captains also alleged that sometimes the companies tricked them out of their share, deceiving them about the price which they have managed to obtain for the fish. Many companies were alleged to only provide a verbal statement of what they had managed to sell the fish for: 
The trusted companies ... always print the calculation as a proof. On the contrary, other companies are not do the same, they wouldn't give the details like ours did, they just informed us verbally. This makes us question the honesty of the company because of the possibility of manipulation.

captain interviewed Benoa (December 2018)

Even where companies do not deliberately deceive, captains and crews were aware that they receive only a tiny proportion of the actual worth of their catch on the global market. The percentage which the company takes from the sales of the total catch was reported by interviewees to vary from company to company:

We divided it by four with the company. For example, if we get one million IDR [US\$70], 750,000 IDR [US\$52] goes to the companies and 250,000 IDR [US\$17] goes to us.

captain, interviewed Benoa (November 2018)

Companies also make deductions from the percentage which is allocated for the captain and his crews for the cost of supplies which they have paid for the voyage. Although the companies own the vessels, the captain and crew are responsible for paying for the fuel, sails, fishing nets, and food supplies used during the voyage. As captain and crew do not have access to sufficient money to pay for their own supplies, the company advances them credit to cover the cost, which is then deducted from the profit-share. As with the kas bon and profit-share payment to crews, this is also an inherent way in which traditional small-scale fishing operates, but which has been adopted by the large, immensely profitable, companies that trade globally. Even though they are in effect employees of the company, captains and their crews are typically jointly responsible for the operational costs of the boats:

It's hard if the fish is out of stock. So sometimes the debt could reach thirty million. So we have to get the results up to thirty million to cover the costs. Because the costs are our debt. For example, we can get around fifty million, but the cost supplies need to be paid, so we add to it. For example, the debt will be 45 million. If the boss is understanding, he doesn't cut it all by once. He would cut it partly, sometimes [by] five million or ten million. But if the boss is not understanding he would cut all at once.

fisher, interviewed Bitung (December 2018)

Whilst not guaranteeing a minimum wage, the profit-share system means that crews also share the risk of not catching any fish, or something going wrong during the voyage. For example, this fisher did not receive a salary for three months because on-board storage facilities had broken spoiling the catch:

A couple months ago, my salary was 'burnt' because the freezer was broken. So we didn't receive any salary [for] three months. They only gave us IDR 500.000 [US\$35] as 'pocket money', but what could you really buy with that money? That's why I was willing to be 
interviewed by you. I really hope that my experience won't be inherited to the younger generation.

fisher interviewed Ambon (November 2018)

Overall, due to the nature of the profit-share system, interviewees referred to fishing as being a 'gamble' in which they did not know whether they could earn enough to support themselves or their families. While they could potentially earn more than working 'on land' in occupations such as construction, there was no certainty about this:

If my children are married, they are not invited to the sea. I forbid, why, because I am already a fisherman. If you can get 10,000 IDR [US\$0.70] at sea, it is better to get 1,000 IDR [US\$0.07] on land. So, I want to have no children who become fishermen. Because it's enough their father is a fisherman. The risk is rather heavy.

older fisher interviewed in Tegal (January 2018)

In commercial fishing as in most sectors, labour costs are the highest cost of production and hence where companies try to reduce costs to maximise profits (Tickler et al. 2018). Prior research has shown how vessel owners reduce expenditure on labour through non-compliance with labour and safety standards, withholding pay and hiring migrant fishers who can be persuaded to work for less than the average wage (Agnew \& Barnes 2004, Tickler et al. 2018). Or they may simply not pay the crew at all, as has often been the case in the Thai and Taiwanese industries (Greenpeace 2018, Vandergeest et al. 2017). This research additionally shows that informal traditional and small-scale fishing payment practices have been co-opted by the global industry to maximise company profitability. Cost-and-profit-sharing allows vessel owners to share the costs and the risks with their crew, despite the fact that they do not hold any ownership or decision-making power, as traditional kin do. Nor do the fishers equally share in the profits, if at all. It is the crews rather than the companies who are bearing the risks of the unreliable nature of fishing and unproductive and unsafe fishing trips. If crews do not catch anything, they do not make any money while still being responsible for repaying the cost of the fishing trip. As the data show, repaying the kas bon and the cost of vessel supplies means fishers make little, and sometimes no, money from the trip, ensuring that they have to make repeated voyages in what might be termed 'cycles of debt repayment'. Such debts provide an opportunity for the continued exploitation and extortion of money from crews as well as ensuring that they do not 'capture the gains' from the profits generated. 


\section{DISCUSSION AND CONCLUSION}

This study has presented the first in-depth empirical research into the working conditions of fishers in Indonesia's export industry. We found conditions to be generally poor, with fishers earning little or no money in comparison to the profits made by the global companies. Further, fishers are risking their health and sometimes their lives, often for little reward. This is not especially unusual, as fishing as an occupationwhether practised sustainably or in the commercial sector-is known worldwide to be difficult and dangerous while generally only supporting a hand-to-mouth existence (Packard Foundation 2018). Simply put, fishing does not pay. As fish stocks are decimated or even obliterated, fishing has become an ever-tougher occupation (FAO 2018). This research has shared two significant findings, which indicate that the global trade is finding new ways to further reduce labour costs to maximise or retain profitability.

Firstly, our research challenges assumptions - within the literature as well as of international companies and policy makers - that the labour risks to fishers are primarily or even solely associated with their migrant status (Vandergeest et al. 2017). Intermediaries - in this case, calo - are utilised by vessel owners and captains to find and mobilise fishers within Indonesia for the some of the same reasons that they are used elsewhere to recruit international migrants. Namely, when no local workforce exists, or at least who are willing to work in the conditions that fishers do for the little money that they do (Jones 2014). For example, intermediaries recruit fishers from poorer parts of Indonesia (e.g., North Central Java) to work on vessels operating out of Benoa (Bali), one of the richest parts of Indonesia. Without intermediaries fulfilling this role, it is likely that captains and vessel owners would have to offer better quality work and higher pay to attract fishers locally. Calo are a way for companiesthrough vessel captains - to reduce the costs of recruitment and of employment. Although acting for a fee, intermediaries are nevertheless deeply embedded in the social relationships inherent in fishing communities in Indonesia, as has been found elsewhere.

Secondly, this research has affirmed and advanced our knowledge of how poor working conditions, including forced labour and trafficking situations, in fishing in low-income countries are used to maximise the profitability of the global industry (e.g., Duong 2018, Tickler et al. 2018). Our research in Indonesia has found that informal working practices which are inherent to traditional, small-scale fishing are co-opted by companies to reduce labour costs. These include how fishers are paid (kas bon), the lack of formal working contracts, and payment through profit-share. Companies profit from their global reach, technological advancement, and low labour costs, which rely on these informal employment practices. However, the inherent social 
protective factors assumed to exist in the traditional, artisanal environment do not extend to domestic migrants hired, often through middlemen, from elsewhere in Indonesia. Fishers continue to bear the costs and risks of fishing, even where they are employees of companies.

Our research has implications both for companies sourcing from Indonesia as well as for governments of importing countries. International brand companies and retail sourcing teams are facing increasing pressure to demonstrate that their businesses source from suppliers with internationally acceptable working conditions. The Modern Slavery Act and other due diligence legislation require companies to prioritise identifying forced labour and trafficking within their supply chains. In purchasing seafood from Indonesia, often with little information gathered, global retailers and buyers face the challenge of determining levels of legal and reputational risk associated with these exploitative conditions. We conclude that, to date, global retailers and buyers are not properly assessing risk in purchasing from Indonesia. The assumption is made that, because no migrant fishers are present in Indonesia, the same risks which are present in Thailand are not present in Indonesia. Our research findings challenge the assumptions underpinning these current risk-based approaches. We argue that a narrow focus on modern slavery risks inadequate or even counterproductive policy responses. Rather, we counter that an understanding of the broader spectrum of exploitative labour hiring and employment practices, which fall short of the definition of modern slavery and which are deliberate profit-maximisation strategies by the companies, are fundamentally necessary. This research highlights that, without the structural and system-wide forced labour conditions that might encourage companies to take action, risks can still be present in industries and in places where they might not be immediately evident.

Our research findings also challenge the main premise underlying national due diligence legislation. That is to say, that forced labour conditions are a result of unscrupulous actors who can, through careful action, in particular responsible sourcing, be rooted out by compliant international companies. We have shown that poor working conditions - including where these extend to extortion and forced labour conditions - are systemic to this industry. Overall, fishers and their families are living 'hand to mouth' and see few viable alternatives 'on land'. It is evident that companies selling seafood to international markets capitalise on such pervasive 'forms of informality' in order to maximise labour flexibility and capital profitability. Yet, the Modern Slavery Act does not require companies to ensure that workers, in this case fishers, at the very end of supply chains capture the gains from being in the global economy. What moral and ethical responsibilities do companies have to ensure that those fishers, and their families, at the end of their supply chains, who bear the daily risks to their lives and to their livelihoods, take an equitable share in the valuable 
profits of the global seafood industry? These are all matters that the current research has raised and presents for further critical discussion by those stakeholders with interests in the Indonesian fishing industry.

\section{Acknowledgements}

We express our gratitude to the British Academy and UK Department for International Development which funded this study under the 'Tackling Slavery, Human Trafficking and Child Labour in Modern Business' Programme. The co-authors would like to thank the wider research team, including Professor Melda Kamil Ariadno, Among Resi and the IOM Indonesia team, Jeremia Nainggolan, Dina Nuriyati for data collection and input to analysis, and an anonymous reviewer, Colin Clark, and Lisa Rende Taylor for their helpful comments on an earlier draft.

\section{REFERENCES}

Agnew, D. J. \& Barnes, C. T. (2004), 'Economic Aspects and Drivers of IUU Fishing: Building a Framework', in K. Gray et al. (eds), Fish Piracy: Combating Illegal, Unreported and Unregulated Fishing (Paris, OECD), 169-200.

Bélanger, D. (2014), 'Labor Migration and Trafficking Among Vietnamese Migrants in Asia', The Annals of the American Academy of Political and Social Science, 653(1): 87-106. https://doi.org/10.1177/0002716213517066

Chapsos, I. \& Hamilton, S. (2018), 'Illegal Fishing and Fisheries Crime as a Transnational Organized Crime in Indonesia', Trends in Organized Crime. https://doi.org/10.1007/s12117-018-9329-8

de Coning, E. (2011), Transnational Organized Crime in the Fishing Industry (Vienna, UN Office on Drugs and Crime).

Derks, A. (2010), 'Migrant Labour and the Politics of Immobilisation: Cambodian Fishermen in Thailand', Asian Journal of Social Sciences, 38: 915-32. https://doi.org/10.1163/156853110X530804

Devlin, J. (2009), 'Modern Day Slavery: Employment Conditions for Foreign Fishing Crews in New Zealand', Australian and New Zealand Maritime Law Journal, 23: 85-98.

Duong, Tiffany T. V. (2018), 'The True Cost of “Cheap” Seafood: An Analysis of Environmental and Human Exploitation in the Seafood Industry', Hastings Environmental Law Journal, 24(2): 279. https://repository.uchastings.edu/hastings_environmental_law_journal/vol24/iss $2 / 6$

EJF (2015), 'Pirates and Slaves: How Overfishing in Thailand Fuels Human Trafficking and the Plundering of Our Oceans', Environmental Justice Foundation. https://ejfoundation.org/reports

EJF (2018a), 'Human Trafficking in Taiwan's Fisheries Sector', Environmental Justice Foundation. https://ejfoundation.org//resources/downloads/EJF-Briefing-Taiwan-2018.pdf

EJF (2018b), 'Out of the Shadows: Improving Transparency in Global Fisheries to Stop Illegal, Unreported and Unregulated Fishing', Environmental Justice Foundation.

https://ejfoundation.org/reports

FAO (2016), 'Global Per Capita Fish Consumption Rises Above 20 Kilograms a Year', Food and Agriculture Organization. http://www.fao.org/news/story/en/item/421871/icode/ 
FAO (2018), The State of the World's Fisheries and Aquaculture, Food and Agriculture Organization. http://www.fao.org/publications/en/

Fernandez, B. (2013), 'Traffickers, Brokers, Employment Agents and Social Networks: The Regulation of Intermediaries in the Migration of Ethiopian Domestic Workers to the Middle East', International Migration Review, 47(4): 814-43. https://doi.org/10.1111/imre.12049

Fudge, J. (2017), 'Modern Slavery, Unfree Labour and the Labour Market: The Social Dynamics of Legal Characterization', Social and Legal Studies, 27(4): 414-34. https://doi.org/10.1177/0964663917746736

Greenpeace (2018), 'Misery at Sea: Human Suffering in Taiwan's Distant Water Fleet'. http://www.greenpeace.org/eastasia/Global/eastasia/publications/campaigns/Oceans/Misery_at_ Sea-Final1.pdf

Human Rights Watch (2018), 'Hidden Chains. Rights Abuses and Forced Labor in Thailand's Fishing Industry'.

https://www.hrw.org/report/2018/01/23/hidden-chains/rights-abuses-and-forced-labor-thailands-fishingindustry\#

Hutton, Jeffrey (2017), 'This Tattooed Indonesian Fisheries Minister Will Blow Your Mind (And Maybe Your Boat)', South China Morning Post, 26 November.

https://www.scmp.com/week-asia/personalities/article/2121483/tattooed-indonesian-fisheries-ministerwill-blow-your-mind

ILO (2007), Work in Fishing Convention, Convention C188, International Labour Organization. https://www.ilo.org/dyn/normlex/en/f?p=NORMLEXPUB:12100:0::NO::P12100_ILO_CODE:C188

ILO (2013), 'Caught at Sea: Forced Labour and Trafficking in Fisheries', International Labour Organization.

https://www.ilo.org/wcmsp5/groups/public/---ed_norm/---declaration/documents/publication/ wcms_214472.pdf

ILO (2016), 'Fishers First: Good Practices to End Labour Exploitation at Sea', International Labour Organization.

https://www.ilo.org/wcmsp5/groups/public/---ed_norm/---declaration/documents/publication/ wcms_515365.pdf

ILO (2017), 'Global Estimates of Modern Slavery: Forced Labour and Forced Marriage', International Labour Organization.

https://www.ilo.org/wcmsp5/groups/public/---dgreports/---dcomm/documents/publication/ wcms_575479.pdf

ILO (2018), 'Women and Men in the Informal Economy: A Statistical Picture', 3rd edn, International Labour Organization.

https://www.ilo.org/wcmsp5/groups/public/---dgreports/---dcomm/documents/publication/ wcms_626831.pdf

IOM (2016), 'Report on Human Trafficking, Forced Labour and Fisheries Crime in the Indonesian Fishing Industry', International Organization on Migration.

https://indonesia.iom.int/sites/default/files/Human $\% 20$ Trafficking $\% 2 \mathrm{C} \% 20$ Forced $\% 20$ Labour $\% 20$ and $\% 20$ Fisheries $\% 20$ Crime $\% 20$ in $\% 20$ the $\% 20$ Indonesian $\% 20$ Fishing $\% 20$ Industry $\% 20-\% 20 \mathrm{IOM} \% 20 . p d f$

Issara Institute \& IJM (International Justice Mission) (2017), 'Not in the Same Boat: Prevalence and Patterns of Labour Abuse Across Thailand's Diverse Fishing Industry'. https://www.issarainstitute.org/library-publications-videos

Jones, K. (2014), “"It was a Whirlwind. A Lot of People Made a Lot of Money”: The Role of Agencies in Facilitating Migration between Poland and the UK between 2004 and 2008', Central and Eastern Migration Review, 3: 105-22. 
Jones, K., Dobree, P., Imru W. \& Morin S. (2017), 'The Migrant Recruitment Industry : Profitability and unethical business practices in Nepal, Paraguay and Kenya', International Labour Organization, Geneva.

https://www.ilo.org/wcmsp5/groups/public/---ed_norm/---declaration/documents/publication/ wcms_574484.pdf

Kelleher, K., Willmann, R. \& Arnason, R. (2009), 'The Sunken Billions: The Economic Justification for Fisheries Reform', The World Bank, Washington, DC.

https://siteresources.worldbank.org/EXTARD/Resources/336681-1224775570533/Sunken BillionsFinal.pdf

LeBaron, G. (2015), 'Unfree Labour Beyond Binaries: Insecurity, Social Hierarchy, and Labour Market Restructuring', International Journal of Feminist Politics, 17(1): 1-19. https://doi.org/10.1080/14616742.2013.813160

Lindquist, J. (2010), 'Labour Recruitment, Circuits of Capital and Gendered Mobility: Reconceptualising the Indonesian Migration Industry', Pacific Affairs, 83(1): 115-32. https://doi.org/10.5509/2010831115

Marschke, M. \& Vandergeest, P. (2016), 'Slavery Scandals: Unpacking Labour Challenges and Policy Responses within the Off-shore Fisheries Sector', Maritime Policy, 68: 39-46. https://doi.org/10.1016/j.marpol.2016.02.009

McDowell R., Mason M. \& Mendoza, M. (2015), 'Slaves May Have Caught the Fish You Bought'. https://www.ap.org/explore/seafood-from-slaves/ap-investigation-slaves-may-have-caught-thefish-you-bought.html

Modern Slavery Act 2015. (c.30) (London, The Stationery Office). http://www.legislation.gov.uk/ukpga/2015/30/contents/enacted

Packard Foundation (2018), 'Trends in Indonesian Marine Resources and Fisheries Management'. https://www.packard.org/insights/resource/trends-in-indonesian-marine-resources-and-fisheriesmanagement/

Prima, I. T., Ash-Shidqi, M. H. \& Aristya, O. (2015), 'Development of Vocational Marine Schools in Indonesia as a Strategy for Rediscovering Indonesia's Maritime Potential', The International Journal of Management Science and Information Technology (IJMSIT), 18: 55-62. https://www.econstor.eu/bitstream/10419/178816/1/IJMSIT_y2015_i18_p055-062.pdf

Robertson, P. (2011), Trafficking of Fishermen in Thailand, International Organization for Migration, Bangkok.

Seafish (2017), 'UK Seafood Industry Overview. HMRC via British Trade Statistics', August. https://www.seafish.org/article/uk-seafood-industry-overview

Seafood Trade Intelligence Portal (no date), 'Indonesia'. https://www.scmp.com/week-asia/personalities/article/2121483/tattooed-indonesian-fisheries-ministerwill-blow-your-mind

Strauss, K. \& Fudge, J. (2013), 'Temporary Work, Agencies and Unfree Labour: Insecurity in the New Work of Work', in J. Fudge \& K. Strauss (eds), Temporary Work, Agencies and Unfree Labour: Insecurity in the New World of Work (New York, Routledge), 1-25.

Stringer, C. Simmons, G. \& Coulston, D. (2011), 'Not in New Zealand's Waters, Surely? Labour and Human Rights Abuses Aboard Foreign Fishing Vessels', Working Paper Series No. 11-01, New Zealand Asia Institute, University of Auckland.

Sunoko, R. \& Huang, H. W. (2014), 'Indonesia Tuna Fisheries Development and Future Strategy', Marine Policy, 43: 174-83. https://doi.org/10.1016/j.marpol.2013.05.011

Surtees, R. (2008), 'Trafficking of Men-A Trend Less Considered. The Case of Belarus and Ukraine', International Organization for Migration, Geneva.

https://www.iom.int/sites/default/files/our_work/ICP/IDM/MRS-36.pdf; https://doi.org/10.18356/52bf0cc6-en 
Tickler, D., Meeuwig, J., Bryant, K., David, F., Forrest, J. A. H., Gordon, E., Joudo Larsen, J. et al. (2018), 'Modern Slavery and the Race to Fish', Nature Communications, 9(1): 4643. https://doi.org/10.1038/s41467-018-07118-9

UNCTAD (2018), '90\% of Fish Stocks Are Used Up_Fisheries Subsidies Must Stop', UN Conference on Trade and Development. https://unctad.org/en/pages/newsdetails.aspx?OriginalVersionID $=1812$

UNODC (2017), 'Fisheries Crime', UN Office on Drugs and Crime. https://www.unodc.org/documents/about-unodc/Campaigns/Fisheries/focus_sheet_PRINT.pdf

Vandergeest, P., Tran, O. \& Marschke, M. (2017), 'Modern Day Slavery in Thai Fisheries: Academic Critique, Practical Action', Critical Asian Studies, 49(3): 461-4. https://doi.org/10.1080/14672715.2017.1339465

Note on the authors

Katharine Jones is an Associate Professor in Centre for Trust, Peace and Social Relations at Coventry University. She is an expert in migration and recruitment intermediaries in international supply chains.

Katharine.Jones@Coventry.ac.uk

David Visser is an independent consultant focussing on supply-chain transparency and human rights in the fishing industry.

Agnes Simic is a Lecturer at Middlesex University.

To cite the article: Katharine Jones, David Visser and Agnes Simic (2019), 'Fishing for export: calo, recruiters, informality, and debt in international supply chains', Journal of the British Academy, 7(s1): 107-130.

DOI https://doi.org/10.5871/jba/007s1.107

This article is licensed under a

Creative Commons Attribution-NonCommercial-NoDerivs 4.0 Unported License.

Journal of the British Academy (ISSN 2052-7217) is published by

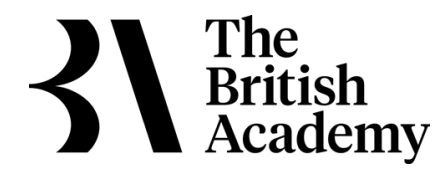

10-11 Carlton House Terrace, London, SW1Y 5AH

www.thebritishacademy.ac.uk 